\title{
PENGARUH SENAM KAKI DIABETIK DENGAN KORAN TERHADAP KADAR GLUKOSA DARAHPADA PENDERITA DIABETES MELLITUS TIPE II
}

\author{
Asniati ${ }^{1}$, Ulfa Hasana ${ }^{2 *}$ \\ D III Keperawatan, STIKes Payung Negeri Pekanbaru, Jln Tamtama No.6, Labuh Baru Timur, \\ Payung Sekaki, Kota Pekanbaru, Riau, Indonesia 28292 \\ Email : ulfahasanah45@yahoo.com
}

Diterima : Desember 2021, Diterbitkan : Desember 2021

\begin{abstract}
ABSTRAK
Latar Belakang: Diabetes Melitus tipe 2 terjadi akibat penurunan sensitivitas terhadap insulin (resistensi insulin) atau akibat penurunan jumlah produksi insulin. Apabila hal ini dibiarkan terus menerus tanpa terapi dapat menyebabkan terjadinya komplikasi, untuk mencegah hal tersebut,salah satu pilar penatalaksananan diabetes adalah latihan jasmani atau olahraga yaitu senam kaki diabetes. Tujuan: Penelitian ini untuk mengetahui pengaruh senam kaki diabetik terhadap kadar glukosa darah pada penderita diabetes melitus tipe II di wilayah kerja Puskesmas Payung Sekaki Pekanbaru. Metode: Penelitian ini bersifat kuantitatif. Desain Penelitian: Desain yang digunakan adalah desain pra eksperimen dengan desain "One Group Pretest and Posttest. Teknik pengambilan sampel: Accidental sampling, yaitu semua penderita Diabetes Mellitus yang ditemui selama penelitian. Untuk penelitian eksperimen sederhana, jumlah anggota sampel adalah 10 sampai 20 orang. Sampel dalam penelitian ini adalah 11 orang. Hasil penelitian ini menyimpulkan bahwa ada pengaruh yang signifikan senam kaki diabetik terhadap kadar glukosa darah, nilai nilai $=0,000<(0,05)$. Penelitian ini merekomendasikan khususnya bagi masyarakat untuk dapat mengenali senam kaki diabetik terhadap perubahan kadar glukosa darah.
\end{abstract}

Kata kunci: Senam Kaki Diabetik, Kadar Glukosa Darah

\begin{abstract}
Background: Diabetes Melitus type 2 caused by the sensitivity to insulin decreased (insulin resistance) or by the decreasing production of insulin. If these cases happen continuously without any medical treatment, it can be complication. To prevent it, one of the solutions for Diabetes Melitus type 2 patient is doing exercise like foot gymnastics.. Objective:This study was to determine the effect of diabetic foot exercise on blood glucose levels in patients with type II diabetes mellitus in the working area of the Umbrella Health Center, Sekaki, Pekanbaru. Methods: This research is quantitative. Research Design: The designused is pre experimental designs with the design of "One Group Pretest and Posttest. Sampling technique: Accidental sampling, namely all patients with Diabetes Mellitus encountered during the study. For simple experimental research, the number of sample members is 10 to 20 people. The sample in this study is 11 people. The results of this study concluded that there was a significant effect of diabetic foot exercise on blood glucose levels, the value of value $=0.000<(0.05)$. This study recommends especially for people to be able to recognize diabetic foot exercises on changes in blood glucose levels. Keywords: Diabetic Foot Exercise, Blood Glucose Level
\end{abstract}

PENDAHULUAN

Perubahan gaya hidup dan sosial ekonomi akibat urbanisasi dan modernisasi terutama di masyarakat kota-kota besar di Indonesia 
menjadi penyebab terjadinya peningkatan prevelensi penyakit degeneratif. Beberapa jenis penyakit yang masuk dalam kelompok penyakit degeneratif seperti Diabetes Mellitus, Jantung Koroner, Hipertensi, dan sebagainya (Kurniawaty 2015). Diabetes Mellitus adalah salah satu diantara penyakit tidak menular yang akan meningkat jumlahnya di masa yang akan datang. Hal ini diduga karena perubahan pola makan masyarakat yang lebih banyak mengonsumsi makanan yang mengandung protein, lemak, gula, garam, dan mengandung sedikit serat.Diabetes melitus (DM) merupakan kumpulan gangguan kronis pada endokrin pankreas, yang ditandai dengan kondisi hiperglikemia yang disebabkan oleh kekurangan insulin relative atau absolut atau oleh rsistensi seluler terhadap kerja insulin (Ulfa \& Wulandari 2020).

Menurut World Health Organization (WHO) diabetes meningkat 4 kali lipat dari 108 juta pada tahun 1980 menjadi sekitar 422 juta orang dewasa mengalami diabetes pada tahun 2014. Hal ini didukung oleh International Diabetes Federation (IDF), pada tahun 2013 terdapat 382 juta orang yang hidup dengan diabetes di dunia. Pada tahun 2035 jumlah tersebut diperkirakan akan meningkat menjadi 592 juta orang. Diperkirakan dari 382 juta orang tersebut 175 juta diantaranya belum terdiagnosis, sehingga dapat mengakibatkan berkembang secara progresif terjadinya komplikasi Diabetes tanpa disadari dan tanpa pencegahan (Ifodatin, 2014). Jumlah penderita diabetes mellitus di Indonesia diprediksi akan terus meningkat, hal ini berkaitan dengan usia harapan hidup semakin meningkat, diet kurang sehat, kegemukan serta gaya hidup modern seperti kurangnya aktivitas atau berolahraga karena kesibukan dan tuntutan penyelesaian pekerjaan (Tarwoto et al., 2012).

Hasil Riset Kesehatan Dasar (2013), Indonesia menempati urutan ke-7 dengan 8,5 juta penderita Diabetes Mellitus. Angka kejadian Diabetes Mellitus mengalami peningkatan dari $1,1 \%$ pada tahun 2007 menjadi $2,1 \%$ pada tahun 2013 dari keseluruhan penduduk sebanyak 250 juta jiwa dan ditahun 2018 berjumlah 2,0\%. Prevalensi Diabetes Mellitus di Indonesia berdasarkan diagnosa dokter sebesar 1,5\% dan berdasarkan diagnosa atau gejala sebesar 2,1\%. Menurut Dinas Kesehatan Provinsi Riau kasus Diabetes Mellitus pada tahun 2018 sebanyak 13,7\% kasus yang tersebar di berbagai Kabupaten di Provinsi Riau. Pada tahun 2019 kasus Diabetes Mellitus sebanyak 39, $4 \%$ yang tersebar di Provinsi Riau. Puskesmas payung sekaki mengalami kasus terbanyak dari berbagai pusat pelayanan di Pekanbaru sebanyak 1.714 kasus pada tahun 2019 dan tahun 2020-2021 kasus Diabetes di Puskesmas setiap bulan bisa mencapai 114 orang perbulan. Jika diabetes mellitus tidak diatasi dengan benar dapat menyebabkan timbulnya banyak komplikasi yang terjadi.

Komplikasi diabetes mellitus terdiri dari kronik dan akut. Komplikasi kronik terbagi menjadi komplikasi makrovaskuler dan mikrovaskuler. Komplikasi makrovaskuler seperti penyakit jantung, penyakit pembuluh darah otak dan penyakit pembuluh darah perifer. Sedangkan komlikasi mikrovaskuler seperti retinopati, nefropati dan neuropati (Mildawati, Diani, \& Wahid 2019). Pengelolaan DM dapat dilakukan dengan terapi farmakologis dan terapi non farmakologis. Pengelolaan terapi farmakologis yaitu pemberian insulin dan obat hipoglikemik oral. Sedangkan non farmakologis meliputi pengendalian berat badan, latihan olahraga, dan diet. Latihan jasmani merupakan salah satu dari empat pilar utama pelaksanaan diabetes mellitus (Wibisana \&Sofiani 2017).

Menurut (Ruben, Rottie, \& Karundeng 2016) bahwa pada saat latihan (senam) kebutusan energi meningkat 
sehingga otot menjadi lebih aktif dan terjadi penurunan kadar gula darah, hal ini juga dilatarbelakangi oleh faktor kontinuitas atau keteraturan pasien dalam mengikuti senam sehingga terjadi penurunan kadar gula darah. Neuropati merupakan gangguan persarafan akibat hiperglikemia. Beberapa tanda dan gejala yang dirasakan pasien adalah kesemutan dan rasa kebas pada anggota gerak terutama kaki. Hal ini mengakibatkan pasien DM tidak merasakan adanya luka pada kaki sehingga pasien tidak menghindari penyebab luka. Hal ini yang menjadi pemicu terjadinya ulkus DM. Salah satu tata laksana dalam mengatasi neuropati adalah dengan senam kaki. Senam kaki merupakan olahraga ringan yang dapat dilakukan oleh pasien DM. Senam kaki dapat meingkatkan sirkulasi darah ke kaki sehingga mengurangi gejala kesemutan dan kebas pada kaki. Senam kaki dapat meningkatkan sensitifitas kaki sehingga efektif untuk mencegah terjadinya neuropati (Dafrianiet, 2019).

\section{METODE PENELITIAN}

Jenis penelitian ini adalah penelitian kuantitatif, desain penelitian yang digunakan pre experimental designs dengan rancangan 'One Group Pretest and Posttest'. Rancangan ini paling tidak sudah dilakukan observasi pertama (pretest) yang memungkinkan adanya perubahanperubahan yang terjadi setelah adanya eksperimen (Notoatmodjo, 2018). Lokasi dan waktu penelitian dilakukan di Puskesmas Payung Sekaki, karena pada data tahun 2019 penderita DM mencapai 1.714 orang dan tahun 2020-2021 kasus Diabetes di Puskesmas setiap bulan bisa mencapai 114 orang perbulan. penelitian ini di mulai pada bulan April sampai Juli 2021. Populasi dalam penelitian ini adalah seluruh pasien penderita Diabetes Mellitus di Wilayah Kerja Puskesmas Payung Sekaki Pekanbaru. Puskesmas payung sekaki mengalami kasus terbanyak dari berbagai pusat pelayanan di Pekanbaru sebanyak 1.714 kasus pada tahun 2019 dan tahun 2020 kasus Diabetes di Puskesmas setiap bulan bisa mencapai 114 orang perbulan. Sampel pada penelitian ini adalah 11 orang yang menderita Diabetes Mellitus di Wilayah Kerja Puskesmas Payung Sekaki Pekanbaru. Instrumen pada penelitian menggunakan alat bantu untuk pengukuran kadar glukosa darah menggunakan glukometer. Sebelum pasien melakukan senam kaki DM terlebih dahulu di periksa kadar gula darah nya, kemudian pasien melakukan senam kaki menggunakan koran selama 1 jam setiap harinya selama 5 hari berturut turut. Pada hari terakhir setelah senam kaki diabetes kadar glukosa darah pasien kembali diperiksa untuk menilai apakah ada perubahan kadar glukosa drah setelah dilakukan senam kaki diabetes selama lima hari.

\section{HASIL DAN PEMBAHASAN}

Berdasarkan hasil penelitian yang telah dilaksanakan pada 25 Juni - 29 Juni 2021 di Wilayah Kerja Puskesmas Payung Sekaki Pekanbaru. Penelitian senam kaki diabetik dilakukan selama 5 hari, maka berikut ini adalah laporan data yang berhasil didapatkan oleh peneliti.

\section{Tabel 1}

Distribusi Karakteristik Gula Darah

Responden Sebelum Melakukan Senam Kaki Di Wilayah Kerja Puskesmas Payung Sekaki Pekanbaru

\begin{tabular}{|c|c|c|}
\hline $\begin{array}{c}\text { Kadar gula } \\
\text { darah sebelum } \\
\text { senam }\end{array}$ & Frekuensi & Persentase \\
\hline $\begin{array}{l}150-199 \mathrm{mg} / \mathrm{dl} \\
>200 \mathrm{mg} / \mathrm{dl}\end{array}$ & $\begin{array}{l}1 \text { orang } \\
10 \text { orang }\end{array}$ & $\begin{array}{c}9 \\
91 \\
\end{array}$ \\
\hline Jumlah & 11 orang & 100 \\
\hline
\end{tabular}

Kadar gula darah responden sebelum melakukan senam kaki, responden yang kadar gula darah $150-199 \mathrm{mg} / \mathrm{dl}$ ada 1 
orang dan kadar gula darah $>200 \mathrm{mg} / \mathrm{dl}$ ada 10 orang.

Tabel 2

Distribusi Karakteristik Gula Darah Responden Setelah Melakukan Senam Kaki Di Wilayah Kerja Puskesmas Payung Sekaki Pekanbaru

\begin{tabular}{ccc}
\hline $\begin{array}{c}\text { Kadar gula } \\
\text { darah } \\
\text { setelah }\end{array}$ & Frekuensi & Persentase \\
senam & & \\
\hline $150-199$ & 8 orang & 73 \\
$>200 \mathrm{mg} / \mathrm{dl}$ & 3 orang & 27 \\
Jumlah & 11 orang & 100 \\
\hline
\end{tabular}

Sebagian besar kadar gula darah responden sesudah melakukan senam kaki mengalami penurunan. Responden yang kadar gula darah $150-199 \mathrm{mg} / \mathrm{dl}$ berjumlah 8 orang dan kadar gula darah > $200 \mathrm{mg} / \mathrm{dl}$ berjumlah 3 orang. Hal ini menggambarkan bahwa responden yang melakukan senam kaki dengan baik dan benar secara teratur relatif mengalami penurunan. Kadar gula darah yang mengalami penurunan menggambarkan terjadinya perbaikan nilai kadar gula darah setelah melakukan senam kaki.

Tabel 3

Perbandingan Rata - Rata Nilai Kadar Gula

Darah Responden Sebelum Dan Sesudah Melakukan Senam Kaki Diabetik Di

Wilayah Kerja Puskesmas

Payung Sekaki Pekanbaru

\begin{tabular}{llll}
\hline $\begin{array}{l}\text { Kadar } \\
\text { gula } \\
\text { darah }\end{array}$ & mean & $\begin{array}{l}\text { Standar } \\
\text { deviasi }\end{array}$ & P value \\
\hline pre & 245,72 & 28,691 & 0,000 \\
post & 191,36 & 26,004 & \\
\hline
\end{tabular}

Berdasarkan hasil penelitian dapat dilihat bahwa rata - rata nilai kadar gula darah sebelum dilakukan senam kaki diabetik adalah 245,72 mg/dl dengan standar deviasi 28,691 mg/dl, sedangkan rata - rata nilai kadar gula darah sesudah dilakukan senam kaki diabetik 191,36 mg/dl dengan standar deviasi 26,004 mg/dl. Hasil uji paired sample T test $\rho$ value $0,000<\alpha(0,05)$, berarti ada pengaruh senam kaki diabetik terhadap kadar glukosa darah pada penderita diabetes mellitus tipe II $\rho$ value $=0,000<(0,05)$.

Senam kaki bertujuan untuk memperbaiki sirkulasi darah sehingga nutrisi ke jaringan lebih lancar, memperkuat otot-otot kecil, otot betis, dan otot paha, komplikasi, menurunkan glukosa darah, serta mengatasi keterbatasan gerak sendi yang sering dialami oleh penderita diabetes mellitus (Sutedjo, 2010).

Menurut penelitian Iilyas (2011) Aktivitas fisik berupa olahraga berguna sebagai kendali gula darah dan penurunan berat badan pada diabetes melitus tipe 2 . Olahraga berperan dalam pengaturan kadar glukosa darah pada diabetes militus tipe 2 . Kurangnya respon terhadap insulin (resistensi insulin) sehingga glukosa tidak dapat masuk ke dalam sel merupakan masalah utama pada diabetes melitus tipe 2 . Permeabilitas membran terhadap glukosa meningkat saat otot berkontraksi karena kontraksi otot memiliki sifat seperti insulin. Maka, pada saat beraktivitas fisik seperti berolahraga, resistensi insulin berkurang.

Sesuai dengan pendapat yang dikemukakan oleh Yanuar (2011) bahwa pada saat latihan (senam) kebutuhan energi meningkat sehingga otot menjadi lebih aktif dan terjadi peningkatan pemakaian glukosa sehingga terjadi penurunan kadar gula darah, hal ini juga dilatarbelakangi oleh faktor kontinuitas atau keteraturan pasien dalam mengikuti senam sehingga terjadi penurunan kadar gula darah.

Menurut Asumsi peneliti adanya perubahan kadar gula darah dengan memberikan senam kaki diabetik selama 5 hari, dimana ada perubahan yang terjadi pada kadar gula darah. Senam kaki mampu menstimulus pankreas dalam memproduksi insulin dalam menekan glukosa darah 


\section{SIMPULAN}

Dari hasil penelitian yang dilakukan pada 11 responden mengenai pengaruh senam kaki diperoleh hasil pengukuran nilai sebelum diberikan senam kaki diabetik sebesar 245,72 mg/dl. Setelah diberikan senam kaki diabetik selama 5 hari terjadi penurunan rata - rata nilai kadar glukosa darah sebesar 191,36 mg/dl. Hasil penelitian menunjukkan adanya penurunan nilai kadar glukosa darah yang signifikan pada kelompok eksperimen setelah diberikan perlakuan

\section{UCAPAN TERIMA KASIH}

Dengan segala kerendahan hati peneliti mengucapkan banyak penghargaan dan terima kasih kepada STIKes payung negeri dan bapak ibu responden serta semua yang terlibat dalam penelitian ini.

\section{DAFAR PUSTAKA}

Diani, Noor, Abdurrahman Wahid, 2019."Hubungan Usia， Jenis Kelamin Dan LamaMenderita Diabetetes Dengan KejadianNeuropatimPerifer Diabetik ( Relationship BetweenAge, Gender and Duration OfDiabetes PatientsWithThe Incidence Diabetic Peripheral Neuropathy )" 3 (2): 31-37.

Endryanto, E (2012), Efektifitas Senam Kaki Diabetes Mellitus Dengan Koran Terhadap Sensitivitas Kaki Pada Pasien Diabetes Mellitus Tipe 2.

Indarti, Erni Tri, and Hendri Palupi. 2018. "Diabetes Mellitus Di Wilayah Kerja Puskesmas Rojoso More Effectivenes Foot Exercise In Improving Blood Circulation For Legs WithReducing Of Glucose Levels For Diabetes Mellitus Patients In Rejoso Health Center," 141- 47.
Kurniawaty, Evi. 2015. "8 Diabetes Mellitus Diabetes Mellitus." Endokrinologie Für Die Praxis, 114$19 . \quad$ https://doi.org/10.1055/b$\underline{0035105347}$

Mildawati, Noor Diani, and Abdurrahman Wahid. 2019. "Hubungan Usia, Jenis Kelamin Dan Lama Menderita Diabetes Dengan Kejadian Neuropati Perifer Diabateik." Caring Nursing Journal 3 (2): 31-37.

Putri, Nurlaili, and Muhammad Isfandiari. 2013. "Hubungan Empat Pilar Pengendalian DM Tipe 2 Dengan Rerata Kadar Gula Darah.” Jurnal Berkala Epidemiologi 1 (2): 234-43

Priyanto. S, (2012), Pengaruh Senam Kaki Terhadap Sensitivitas Kaki Dan Kadar Gula Darah Pada Agregat Lansia DM DI Magelang.

Ruben, Graceistin, Julia Rottie, and Michael Y Karundeng. 2016. "Pengaruh Senam Kaki Diabetes Terhadap Perubahan Kadar Gula Darah Pada Pasien Diabetes Melitus Tipe 2." EJournal Keperawatan (EKp) 4: 1-5.

Sukawana, I Wayan, Ni Made Wedri, and I Made Sukarja. 2018. "Senam Kaki Meningkatkan Sensasi Sensoris Diabetisi" 11 (1): 1-8

Ulfa Husnul Fata, Nawang Wulandari, Luty Trijayanti. 2020. "Pengetahuan Dan Sikap Tentang Perawatan Kaki Diabetes Pada Penderita Diabetes Melitus." Jurnal Keperawatan 12 (1): 101-6.

Wibisana, Elang, and Yani Sofiani. 2017. "Pengaruh Senam Kaki Terhadap Kadar Gula Darah Pasien Diabetes Melitus Di Rsu Serang Provinsi Banten.” Jurnal JKFT 2 (2): 107 https://doi.org/10.31000/jkft.v2i 1.698 